\title{
2017: The Year of European Populism?
}

After the shocks of Brexit and Trump in 2016, what should we expect for 2017? Many people fear that populism and nationalism will continue to spread, undermining international cooperation and economic exchange as well as political integration, particularly in the EU. Indeed, the upcoming elections in various European countries, including France, the Netherlands, Germany and possibly Italy, all have the possibility to bring populists to power. While unlikely, it is certainly possible that Marine Le Pen could win France's presidential election - a victory that would trigger a political earthquake and rock the very foundations of the EU. In the Netherlands, the Geert Wilders-fronted Party for Freedom may yet emerge as the strongest party in the Dutch parliament. Germany is probably less vulnerable to the populist influence due to its favourable economic situation, but Angela Merkel has lost a lot of political support, especially in her own party, due to her spontaneous decision to let over a million refugees enter the country. The looming conflict between Merkel and the conservative wing of the CDU and the Bavarian CSU may turn out to be a major weakness in her re-election campaign. That could help the social democrats, but the right-wing populist AfD may also benefit. Surveys show that electoral support for the AfD is currently far from levels that would allow it to enter government. But that could change, and as we have seen, opinion polls can be misleading. Another political risk is that early elections might be called in Italy, where the Five Star Movement could seize power.

What can be done to halt the advance of populism and populist economic policies in Europe? Moderate political parties will need to explain to the electorate what the populist agenda is and why populist policies lead to bad outcomes. Furthermore, they will need to convince the electorate that they themselves have something better to offer. This will be no easy task.

What are the key features of populist economic policies? Firstly, populists usually describe society as being divided into two homogenous and antagonistic groups: the people are often juxtaposed with a ruling elite that is seen as corrupt. Populists claim that, once in power, they will implement policies that reflect the will of the people, rather than the elite. In his electoral campaign, for instance, Donald Trump argued that a corrupt "Washington elite" had captured the US government and that he wanted to hand back the power to "the people".

A second characteristic of the populist agenda is that it overemphasises the negative effects of globalisation. Populists reject immigration and are opposed to political integration and the international institutions underpinning and regulating economic exchange among countries. They reject institutions that restrain national sovereignty, such as the World Trade Organization and the EU, and they dislike any checks and balances that may prevent them from implementing their policies.

Thirdly, populists favour expansionary fiscal policy and tend to brush aside the bothersome existence of government budget constraints. When the Syriza Party came to power in Greece in January 2015, for example, it promised an end to austerity and increases in public spending. It neglected to explain, however, who exactly was supposed to pay for this additional spending, given that Greece had no access to international capital markets at the time due to its high levels of debt.

Why do populist policies lead to bad outcomes? Populists offer simple strategies to deal with complex problems and, in most cases, those strategies do not work. The claim that our societies reflect a conflict between the people and a corrupt elite ignores the fact that different groups of the population have different interests, and that there is neither a homogenous will of the people nor a homogenous elite. Our societies consist of different groups with diverging interests. Democracies need institutions to balance these different interests by way of compromise.

The populist answer to economic difficulties such as stagnating wages or unemployment for lowskilled workers is to limit immigration. This entirely overlooks the fact that the labour market impact 
of immigration depends on the type of immigration in question, and it ignores that immigration is usually not a major factor driving unemployment. Populists seek to protect those who lose their jobs through foreign competition by restricting imports, regardless of the fact that protectionism drives up domestic prices and triggers countermeasures by other countries. Populists want to overcome the limitations of public funding by increasing public debt, irrespective of whether or not this undermines the sustainability of public finances.

While populist parties usually give simplistic answers and support harmful policies, this of course does not imply that mainstream parties always offer balanced and rational views. Populism may creep into their policies and rhetoric, such as when UK Prime Minister Theresa May recently denounced what she called the members of the "rootless international elite" as "citizens of nowhere" who lack the "spirit of citizenship". More generally, this illustrates how populism should be seen as a particular political agenda, rather than the property of individual politicians or parties.

What is the alternative to the populist agenda? Three factors are of key importance. Firstly, there is no point in denying that populists sometimes address key issues. Immigration, the eurozone crisis and the fact that not everybody benefits from globalisation are all important and relevant issues. Many people are justifiably angry about banks that distribute high bonuses to their managers in good times and rely on government support in bad times, but what is the best way to address these issues? This leads to the second point: moderate politicians should be open about the limits to what national governments and the EU can achieve. The forces of economic development will always create new jobs and wipe out existing ones. The promise that this process of change can be halted by restricting international economic exchange is an illusion, as is the idea that those who lose out as a result of change can be fully compensated. But what governments can do is offer a welfare state that prevents those who lose their jobs from falling into poverty and offer education systems that enable people to adjust to change and seize new opportunities.

What can the EU realistically hope to achieve? By developing the European internal market, the EU offers a wealth of opportunities. Firms can trade or invest across borders, people can seek employment in other countries and students can attend universities throughout Europe. The EU also helps its poorer members to develop their infrastructure, thus supporting economic convergence. Key elements of economic and social policy, however, remain the responsibility of the individual member states. If countries have excessively high taxes, if they elect ineffective administrations or if their labour markets are too rigid to allow young people to find employment, there is little that the EU can do to fix this. Yet it is common for national governments to blame the EU for domestic economic difficulties. This is a form of populism often employed by mainstream politicians.

Thirdly, the mainstream political agenda needs to do more than defend the status quo: it needs to demonstrate that it can bring about change for the better. A plausible strategy, for instance, is needed to deal with the biggest challenge in European economic policy, namely the ongoing euro crisis. The problem is that Europe is deeply divided. In most Northern European countries, the prevailing view is that the eurozone needs flexible labour markets and hard government budget constraints. The current economic difficulties in the eurozone are seen as reflecting the lack of competitiveness among Southern European countries. In Southern Europe, by contrast, the dominating view denounces restrictive fiscal policies as the main obstacle to economic recovery. Finding compromises that reconcile these two opposing views will be a hugely challenging task. Progress may be easier to achieve in other areas, such as the plans to formulate a common European security policy or EU policies to protect external borders.

Clemens Fuest, Center for Economic Studies, Munich, Germany.
It will be an uphill struggle to convince the electorate that the mainstream political agenda, with its emphasis on compromise and trade-offs, is more attractive than the simple, emotional and radical messages of populists. In the end, however, voters in Europe will hopefully resist the lure of populism; especially bearing in mind that, throughout Europe's history, nationalism and xenophobia have always done far more harm than good. 